\title{
Ecology and Taxonomy of Some Mollusk Species at EI Malaha Ryan Offshore Area, Gulf of Aqaba, Egypt
}

\author{
El Halaby OM, Khalil MMM \\ Geology Department, Faculty of Science, Damietta University
}

Received: 29 August 2015 / Accepted: 21 September 2015

*Corresponding author (email: mmagdym@yahoo.com)

\begin{abstract}
This paper deals with the taxonomy and ecology of 35 shells of Mollusk species identified from 12 samples collected from El Malaha Rayan offshore area. The study area is situated between south wadi El Malaha Rayan and Wadi El Malaha El Atchan offshore area. The study area has a length of $300 \mathrm{~m}$ and a width of $150 \mathrm{~m}$. and El Malaha Rayan offshore areas represent the tidal and littoral zones.There are four wadies passing through the area of Wadi El Malaha Rayan and they pour their Flash flood in the Gulf of Aqaba. The marine environment of the study area is not influenced by the flash flood of the four wadies (Wadi El Wageran, Wadi El Malaha Rayan, Wadi El Malaha El Atchan and Wadi El Mohaymed).

There are two groups of cluster analyses in the dendogram. The first group (A) located in the Tidal zone and include 33 Mollusk species (14 species from class Bivalvia and 19 species from class Gastropoda). These species exists in warm turbid water mostly caused by flash floods and they represent the tidal zone.The other group (B) located in the littoral zone and include 35 Mollusk species (14 species from class Bivalvia and 21 species from class Gastropoda).
\end{abstract}

Keywords: Environmental Geology, Mollusk, Gastropoda, Ecology.

\section{Introduction}

Wadi El Malaha Rayan offshore area is influenced by four wadies and it is situated between Taba and Newiba city in the Gulf of Aqaba. Marine environment of the area is not influenced by the flash floods of the four wadies (Wadi El Wageran, Wadi El Malaha Rayan, Wadi El Malaha El Atchan and Wadi El Mohaymed) (Fig. 1) the amount of flash flood of wadies are less than $8 \mathrm{~mm} /$ day (Table 1). Ball 1937 used this equition $\mathrm{V}=750 \times \mathrm{A}(\mathrm{R}-8)$.

$\mathrm{V}=$ maximum volume of runoff $\left(\mathrm{m}^{3}\right), \mathrm{R}=$ Average maximum rain fall (in one day $\mathrm{mm}$ ), $\mathrm{A}=$ Basin area of wadi $\left(\mathrm{km}^{2}\right)$.
The amount of water runoff in the study area is less than $1.6 \mathrm{~mm} /$ month, therefore The marine environment of the study area is not affected by flash floods, thus it is characterized by diversity of the mollusk shells.

The study area is situated in the offshore area of wadi El Malaha Rayan. The length of the study area is $300 \mathrm{~m}$ and width is $150 \mathrm{~m}$ from shoreline of El Malaha Rayan. It represents two types of environment (tidal and littoral zone).

The northern beach of the study area is gravels with coarse sand and the southern beach area is sandy. Some sea grasses are growing in the sandy rock bottom. Also some pitches of sand 
and shale were found growing with sea grasses and algae in the littoral zone.

The present study deals with the taxonomy and ecology of 35 shells of Mollusk species identified from 12 samples collected from El Malaha Rayan offshore area. Four samples were collected from tidal zone in a depth ranges between $0.5 \mathrm{~m}$ and $1 \mathrm{~m}$. Beginning from sample $1(290825.62 \mathrm{~N} 344124.96 \mathrm{E})$ to sample 4 ( 29 $0816.90 \mathrm{~N} 344119.43$ E) (Fig. 2). Another 8 samples were collected from littoral zone within a depth range between $3 \mathrm{~m}$ and $7 \mathrm{~m}$. These samples collected from four profiles, the distance between profiles is $100 \mathrm{~m}$ and distance between samples in each profile is $50 \mathrm{~m}$.

Physical condition of marine water is quite currents, warm water, sim-clear and turbid water during two seasons winter and autumn. Table (2) shows frequency of species in each sample, depth and marine environment in the study area.

The taxonomy of the recognized species was revised according to the classification scheme of Treatise on Invertebrate Paleontology (Moore 1969, 1971).

Table 1. Ratio of Rain in the Four wadies

\begin{tabular}{|l|l|l|l|l|l|l|l|l|l|l|l|l|}
\hline Month & 1 & 2 & 3 & 4 & 5 & 6 & 7 & 8 & 9 & 10 & 11 & 12 \\
\hline $\begin{array}{l}\text { Rain } \\
\text { mmlmonth }\end{array}$ & Trace & 0.6 & 1.6 & Trace & - & - & - & - & - & 0.8 & Trace & 1 \\
\hline
\end{tabular}

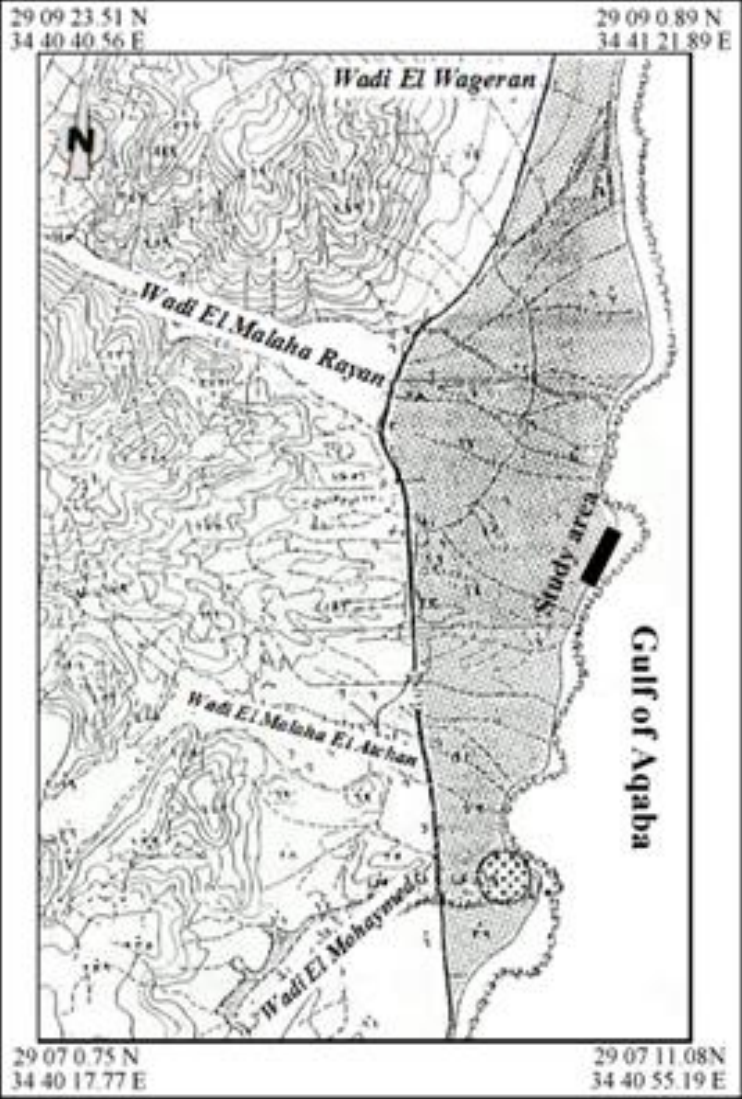

Fig. 1 Location of study offshore area in Gulf of Aqaba

\section{Diversity of Mollusk assemblages}

To better evaluate the nature of the recognized assemblages, the diversity distribution of
Mollusk among samples has been mapped. For each sample, the diversity has been calculated by using the Yule-Simpson Index.

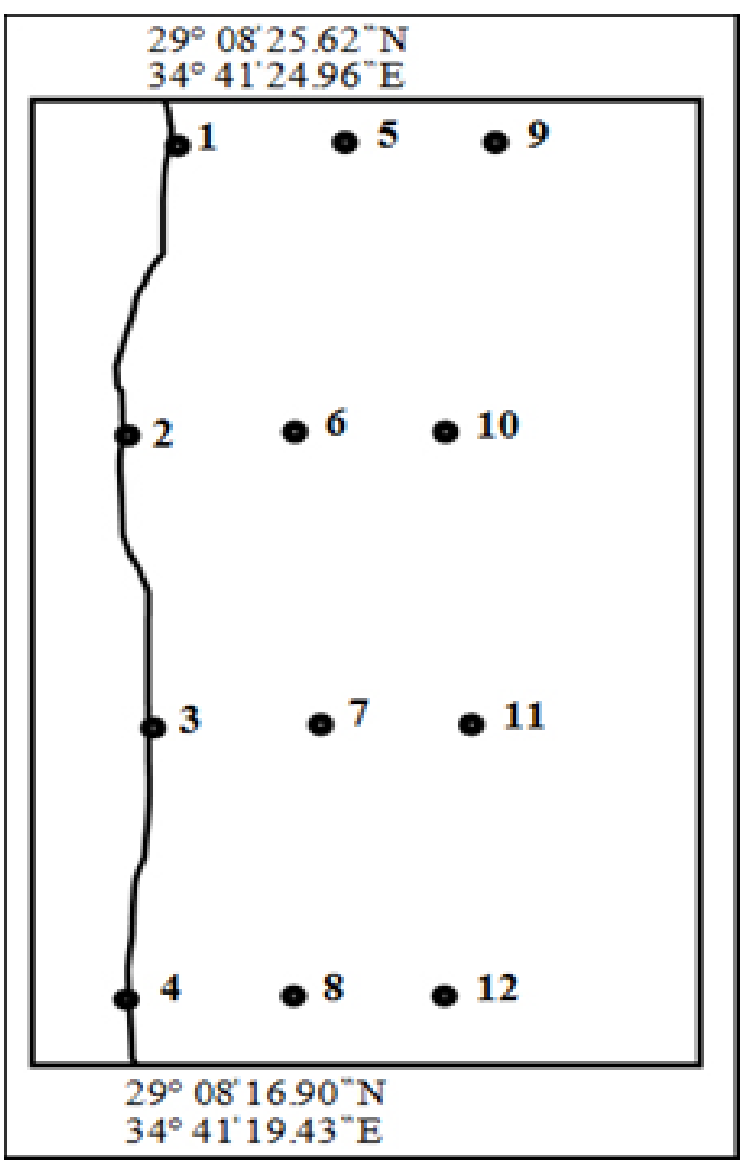

Fig. 2 Location of samples in study offshore area. 


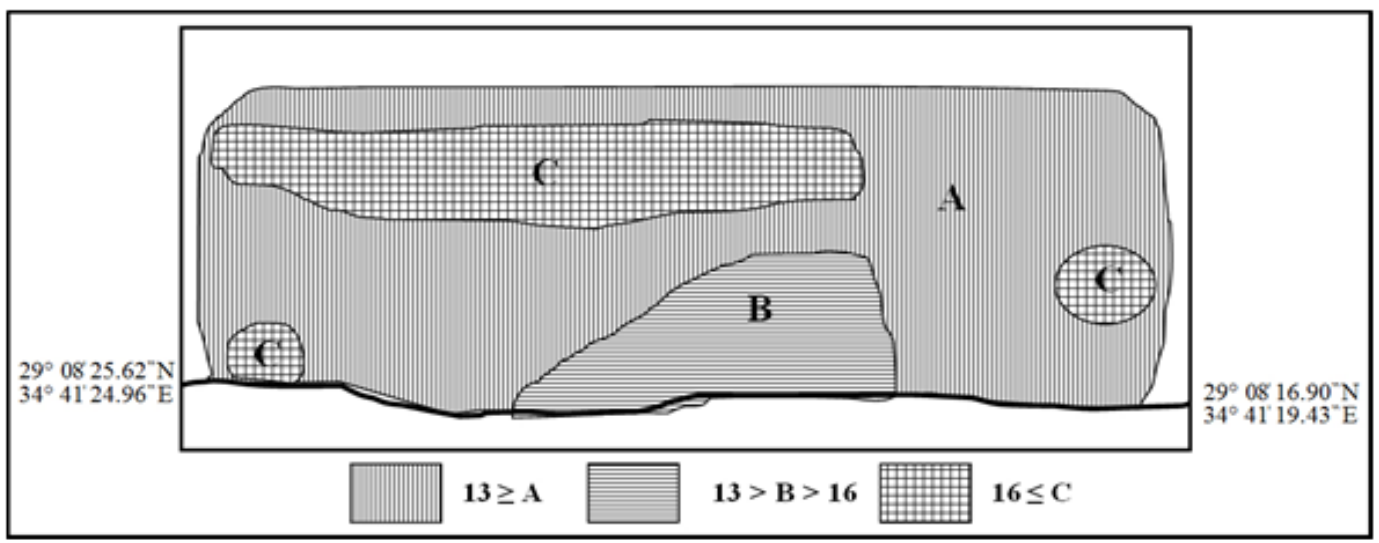

Fig. 3 Diversity map of study area.

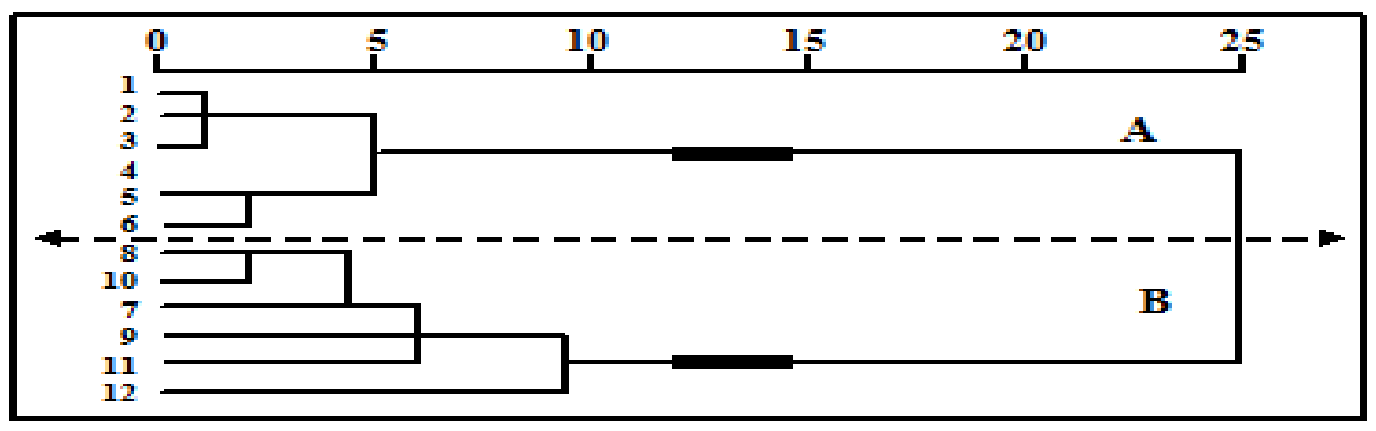

Fig. 4 Dendogram of cluster analysis of samples.

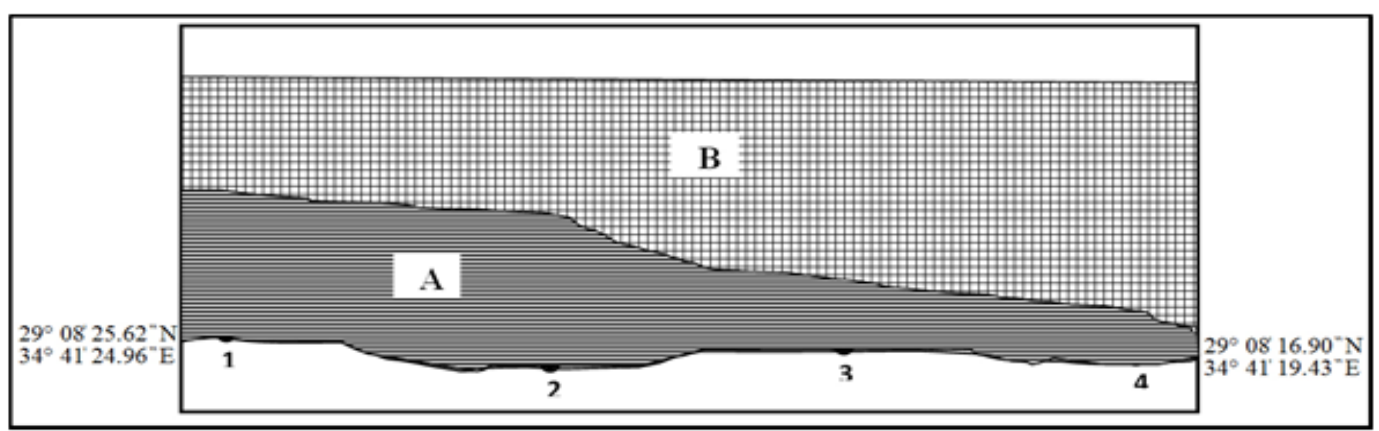

Fig. 5 The two group of cluster analysis in study area.

\section{Cluster analysis}

Cluster analysis of samples enables to segregate two groups of samples after their Mollusk content. The analysis of variance determined highly significant species for the segregation of these groups (Table 3 and Fig. 5).

\section{Analysis of variance}

Analysis of variance used on group of cluster analysis. Each group of cluster analysis content on several frequencies of species it detected significantly species in each group of cluster analysis depending on compare between frequencies of species in each sample.

To detect the species which are significantly affecting the clustering of each one of the clustering procedures, a multivariante (ANOVA) has been performed for each species to test the difference between the variance in the frequencies of the species in all the samples of a given area and the variance of the averages of the frequencies of the same species in each cluster group (between the groups) (Table 3). 
Table 2. Frequency of species and depth of samples.

\begin{tabular}{|c|c|c|c|c|c|c|c|c|c|c|c|c|}
\hline Marine environment & \multicolumn{4}{|c|}{ Tidal zone } & \multicolumn{8}{|c|}{ Littoral zone } \\
\hline $\begin{array}{l}\text { Depth m. } \\
\text { Species }\end{array}$ & 0.2 & 0.5 & 0.4 & 0.3 & 1.5 & 1.4 & 3.6 & 3.2 & 5.8 & 6.4 & 5.7 & 7 \\
\hline $\begin{array}{lll}\text { Species } & \text { Samples } & \text { Species } \\
\end{array}$ & 1 & 2 & 3 & 4 & 5 & 6 & 7 & 8 & 9 & 10 & 11 & 12 \\
\hline Glycymeris pectunculus & 2 & 4 & 2 & 3 & 6 & 0 & 1 & 0 & 1 & 0 & 0 & 1 \\
\hline Modiolus auriculatus & 4 & 5 & 2 & 6 & 7 & 8 & 0 & 0 & 2 & 0 & 2 & 0 \\
\hline Chama squamosa & 12 & 10 & 11 & 13 & 14 & 15 & 3 & 0 & 0 & 2 & 4 & 3 \\
\hline Mactra glauca & 4 & 3 & 4 & 2 & 3 & 0 & 1 & 0 & 0 & 0 & 0 & 0 \\
\hline Asaphis deflorata & 2 & 4 & 6 & 8 & 0 & 0 & 0 & 0 & 2 & 2 & 3 & 1 \\
\hline Tellina pulchella & 2 & 5 & 6 & 0 & 0 & 0 & 0 & 1 & 2 & 1 & 0 & 0 \\
\hline Tellina radiata & 3 & 2 & 4 & 1 & 0 & 0 & 1 & 2 & 2 & 1 & 1 & 1 \\
\hline Tellina rugosa & 4 & 3 & 1 & 2 & 1 & 1 & 2 & 2 & 0 & 0 & 0 & 0 \\
\hline Tridacna gigas & 0 & 0 & 1 & 5 & 0 & 1 & 2 & 0 & 0 & 1 & 2 & 0 \\
\hline Tridacna squamosa & 2 & 0 & 2 & 0 & 5 & 2 & 0 & 1 & 0 & 3 & 0 & 0 \\
\hline Venerupis aurea & 4 & 6 & 5 & 2 & 4 & 5 & 0 & 1 & 0 & 0 & 0 & 2 \\
\hline Circe pectinata & 11 & 13 & 14 & 15 & 12 & 10 & 3 & 2 & 3 & 0 & 3 & 5 \\
\hline Circe scripta & 5 & 4 & 6 & 2 & 1 & 0 & 1 & 1 & 0 & 0 & 0 & 0 \\
\hline Venus reticulata & 2 & 3 & 1 & 5 & 0 & 2 & 2 & 2 & 0 & 2 & 0 & 2 \\
\hline Total Bivalvia & 57 & 62 & 65 & 64 & 53 & 44 & 16 & 12 & 12 & 12 & 15 & 15 \\
\hline Bathybembix argenteonitens (Lschke) & 1 & 0 & 3 & 0 & 0 & 0 & 0 & 0 & 1 & 2 & 0 & 2 \\
\hline Tegula Fasciata & 0 & 0 & 0 & 1 & 0 & 0 & 1 & 2 & 0 & 2 & 2 & 1 \\
\hline Tegula omphalius & 2 & 0 & 3 & 0 & 0 & 1 & 0 & 0 & 3 & 0 & 5 & 2 \\
\hline Clanculus pharaonium & 0 & 0 & 0 & 2 & 0 & 1 & 0 & 3 & 0 & 1 & 0 & 2 \\
\hline Tectus dentatus & 0 & 1 & 0 & 0 & 1 & 0 & 1 & 2 & 0 & 2 & 3 & 4 \\
\hline Umbonium giganteum & 0 & 0 & 0 & 1 & 0 & 0 & 2 & 0 & 4 & 2 & 0 & 1 \\
\hline Turbo argyrostomus & 1 & 3 & 1 & 2 & 2 & 1 & 11 & 8 & 7 & 6 & 0 & 9 \\
\hline Rissoa violacea & 0 & 0 & 2 & 0 & 0 & 2 & 1 & 5 & 5 & 2 & 4 & 6 \\
\hline Barleeia rubra & 0 & 1 & 0 & 1 & 0 & 0 & 0 & 5 & 6 & 6 & 7 & 2 \\
\hline Amaea magnifica & 2 & 1 & 0 & 0 & 3 & 3 & 5 & 3 & 0 & 0 & 6 & 8 \\
\hline Strombus gibberulus albus & 2 & 1 & 4 & 3 & 2 & 1 & 9 & 11 & 3 & 10 & 11 & 2 \\
\hline Conus daucus & 4 & 2 & 4 & 5 & 3 & 2 & 15 & 10 & 14 & 15 & 12 & 17 \\
\hline Conus arenatus & 1 & 1 & 1 & 0 & 0 & 0 & 4 & 3 & 5 & 7 & 5 & 0 \\
\hline Conus glaucus & 0 & 0 & 0 & 1 & 1 & 1 & 3 & 6 & 4 & 7 & 3 & 1 \\
\hline Conus flavidus & 2 & 1 & 1 & 0 & 1 & 5 & 5 & 8 & 8 & 3 & 0 & 0 \\
\hline Conus textile & 4 & 0 & 0 & 0 & 0 & 3 & 2 & 2 & 2 & 5 & 4 & 1 \\
\hline Terebra dislocate & 2 & 2 & 1 & 1 & 4 & 5 & 9 & 10 & 9 & 8 & 9 & 11 \\
\hline Harpa costata & 0 & 0 & 0 & 0 & 0 & 0 & 1 & 0 & 0 & 0 & 2 & 1 \\
\hline Harpa davidis & 0 & 0 & 0 & 0 & 0 & 0 & 0 & 2 & 0 & 2 & 0 & 0 \\
\hline Vasum muricatum & 2 & 1 & 0 & 1 & 0 & 1 & 3 & 5 & 2 & 1 & 4 & 3 \\
\hline Bulla striata & 2 & 1 & 0 & 0 & 2 & 2 & 5 & 6 & 4 & 5 & 7 & 9 \\
\hline Total Gastropoda & 25 & 15 & 20 & 18 & 19 & 28 & 77 & 91 & 77 & 86 & 84 & 82 \\
\hline Total species & 82 & 77 & 85 & 82 & 72 & 72 & 93 & 103 & 89 & 98 & 99 & 97 \\
\hline
\end{tabular}

\section{Highly significant species in group A}

This group (A) was recorded in the tidal zone and the analysis of variance enables to determine 6 highly significant species in this environment. These species belonged to 4,2 species from highly significant class bivalvia and class gastropoda respectively (table 3 ).

\section{Highly significant species in group $B$}

This group (B) was recorded in the littoral zone which is an area of sea grasses growing on shale. 
The analysis of variance determined 14 highly significant species in this environment. These species belonged to 2, 12 species from highly significant class bivalvia and class gastropoda respectively (Table 3).

Table 3. Cluster analysis and highly significant species in group (highly significant species $<0.005$ ).

\begin{tabular}{|c|c|c|c|c|}
\hline \multirow{2}{*}{ Species } & \multicolumn{2}{|c|}{ Cluster analysis } & \multicolumn{2}{|c|}{ Significant species } \\
\hline & Group A & Group B & Group A & Group B \\
\hline Glycymeris pectunculus (Linnaeus 1780) & 3.62 & 0.52 & 0.019 & 0.037 \\
\hline Modiolus auriculatus Krauss 1848 & 6.81 & 0.69 & 0.002 & 0.109 \\
\hline Chama squamosa (Solander 1761) & 15.96 & 2.07 & 0 & 0.013 \\
\hline Mactra glauca Born 1778 & 3.40 & 0.17 & 0.007 & 0.28 \\
\hline Asaphis deflorata (Linnaeus 1758) & 4.26 & 1.38 & 0.054 & 0.018 \\
\hline Tellina pulchella Lamarck 1818 & 2.77 & 0.69 & 0.108 & 0.055 \\
\hline Tellina radiata Linnaeus 1758 & 2.13 & 1.38 & 0.054 & 0 \\
\hline Tellina rugosa Born 1778 & 2.55 & 0.69 & 0.012 & 0.109 \\
\hline Tridacna gigas (Linnaeus 1758) & 1.49 & 0.86 & 0.201 & 0.049 \\
\hline Tridacna squamosa Lamarck 1819 & 2.34 & 0.69 & 0.058 & 0.16 \\
\hline Venerupis aurea Gmelin 1791 & 5.53 & 0.52 & 0.001 & 0.132 \\
\hline Circe pectinata (Linnaeus 1758) & 15.96 & 2.76 & 0 & 0.003 \\
\hline Circe scripta Linnaeus 1758 & 3.83 & 0.35 & 0.027 & 0.109 \\
\hline Venus reticulata Linnaeus 1758 & 2.77 & 1.38 & 0.027 & 0.009 \\
\hline Bathybembix argenteonitens (Lschke 1871) & 0.85 & 0.86 & 0.235 & 0.049 \\
\hline Tegula Fasciata (Born 1778) & 0.21 & 1.38 & 0.363 & 0.003 \\
\hline Tegula omphalius Philippi 1847 & 1.28 & 1.73 & 0.111 & 0.057 \\
\hline Clanculus pharaonium (Linnaeus 1758) & 0.64 & 1.04 & 0.203 & 0.061 \\
\hline Tectus dentatus (Forskal 1775) & 0.43 & 2.07 & 0.175 & 0.006 \\
\hline Umbonium giganteum (Lesson 1831$)$ & 0.21 & 1.55 & 0.363 & 0.028 \\
\hline Turbo argyrostomus Linnaeus 1758 & 2.13 & 7.08 & 0.004 & 0.002 \\
\hline Rissoa violacea Desmarest 1814 & 0.85 & 3.97 & 0.175 & 0.001 \\
\hline Barleeia rubra (J. Adams 1795) & 0.43 & 4.49 & 0.175 & 0.004 \\
\hline Amaea magnifica (Sowerby 1844) & 1.91 & 3.80 & 0.045 & 0.017 \\
\hline Strombus gibberulus albus Morch 1852 & 2.77 & 7.94 & 0.006 & 0.002 \\
\hline Conus daucus Bruguiere 1792 & 4.26 & 14.34 & 0.001 & 0 \\
\hline Conus arenatus Bruguiere 1792 & 0.64 & 4.15 & 0.076 & 0.003 \\
\hline Conus glaucus Linnaeus 1758 & 0.64 & 4.15 & 0.076 & 0.002 \\
\hline Conus flavidus Lamarck 1822 & 2.13 & 4.15 & 0.067 & 0.018 \\
\hline Conus textile Linnaeus 1758 & 1.49 & 2.76 & 0.18 & 0.002 \\
\hline Terebra dislocata (Say 1822) & 3.19 & 9.67 & 0.014 & 0 \\
\hline Harpa costata Linnaeus 1758 & & 0.69 &. & 0.055 \\
\hline Harpa davidis Röding 1798 & & 0.69 & 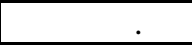 & 0.109 \\
\hline Vasum muricatum (Born 1778) & 1.06 & 3.11 & 0.042 & 0.001 \\
\hline Bulla striata Bruguiere 1792 & 1.49 & 6.22 & 0.034 & 0 \\
\hline Total highly significant species & & & 6 & 14 \\
\hline
\end{tabular}

\section{Systematic}

All the species considered in the present study are well known and described in the literatures. Their description is not repeated in this paper, Only the work giving the diagnosis followed in identifying the different species are given as synonymy. For each species, already known geographic and ecological distributions are discussed. The classification of Moore (1969 1971) in the Treatise on Invertebrate Paleontology is followed (table 5).

Class Bivalvia

In El Malaha Rayan offshore area three orders are recorded Arcoida, Mytiloida and Veneroida. This order includes in the study area 10 genera which are known to live in the brackish water and in turbid water (table 5). 
Subclass Pteriomorphia

Order Arcoida

In El Malaha Rayan offshore area, this order includes one species. This species live in the shallow water, agitated currents and turbid water. It is associated with many species of aquatic plants.
Superfamily Limopsacea

Family Glycymeridae

Subfamily Glycymeridinae

Genus Glycymeris Da Costa 1778

1- Glycymeris pectunculus (Linnaeus 1780)

Pl. 1, Fig. 1a,b

Table 4. Percentage, diversity and standard deviation of each species.

\begin{tabular}{|c|c|c|c|c|c|}
\hline Species & No. St. & $\stackrel{\vec{\pi}}{0} \dot{n}$ & 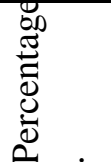 & 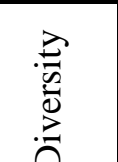 & $\dot{D}$ \\
\hline Glycymeris pectunculus (Linnaeus 1780) & 8 & 20 & 1.91 & 7.30 & 1.87 \\
\hline Modiolus auriculatus Krauss 1848 & 8 & 36 & 3.43 & 7.59 & 2.92 \\
\hline Chama squamosa (Solander 1761) & 10 & 87 & 8.29 & 8.26 & 5.74 \\
\hline Mactra glauca Born 1778 & 6 & 17 & 1.62 & 7.16 & 1.68 \\
\hline Asaphis deflorata (Linnaeus 1758) & 8 & 28 & 2.67 & 6.78 & 2.57 \\
\hline Tellina pulchella Lamarck 1818 & 6 & 17 & 1.62 & 5.04 & 2.07 \\
\hline Tellina radiata Linnaeus 1758 & 10 & 18 & 1.72 & 12.75 & 1.17 \\
\hline Tellina rugosa Born 1778 & 8 & 16 & 1.53 & 10 & 1.3 \\
\hline Tridacna gigas (Linnaeus 1758) & 6 & 12 & 1.14 & 6.56 & 1.6 \\
\hline Tridacna squamosa Lamarck 1819 & 6 & 15 & 1.43 & 5.50 & 1.48 \\
\hline Venerupis aurea Gmelin 1791 & 8 & 29 & 2.76 & 11.05 & 1.42 \\
\hline Circe pectinata (Linnaeus 1758) & 11 & 91 & 8.67 & 8.29 & 2.27 \\
\hline Circe scripta Linnaeus 1758 & 7 & 20 & 1.91 & 8.90 & 5.4 \\
\hline Venus reticulata Linnaeus 1758 & 9 & 21 & 2.00 & 5.94 & 2.15 \\
\hline Bathybembix argenteonitens (Lschke 1871) & 5 & 9 & 0.86 & 7.20 & 1.06 \\
\hline Tegula Fasciata (Born 1778) & 6 & 9 & 0.86 & 12.00 & 0.87 \\
\hline Tegula omphalius Philippi 1847 & 6 & 16 & 1.53 & 6.67 & 1.67 \\
\hline Clanculus pharaonium (Linnaeus 1758) & 5 & 9 & 0.86 & 7.20 & 1.06 \\
\hline Tectus dentatus (Forskal 1775) & 7 & 14 & 1.33 & 8.27 & 1.34 \\
\hline Umbonium giganteum (Lesson 1831) & 5 & 10 & 0.95 & 5.63 & 1.27 \\
\hline Turbo argyrostomus Linnaeus 1758 & 11 & 51 & 4.86 & 7.97 & 3.74 \\
\hline Rissoa violacea Desmarest 1814 & 8 & 27 & 2.57 & 7.98 & 2.22 \\
\hline Barleeia rubra (J. Adams 1795) & 7 & 28 & 2.67 & 6.10 & 2.81 \\
\hline Amaea magnifica (Sowerby 1844) & 8 & 31 & 2.96 & 7.38 & 2.64 \\
\hline Strombus gibberulus albus Morch 1852 & 12 & 59 & 5.62 & 8.31 & 4.06 \\
\hline Conus daucus Bruguiere 1792 & 12 & 103 & 9.82 & 9.14 & 5.79 \\
\hline Conus arenatus Bruguiere 1792 & 8 & 27 & 2.57 & 7.31 & 2.38 \\
\hline Conus glaucus Linnaeus 1758 & 9 & 27 & 2.57 & 7.02 & 2.45 \\
\hline Conus flavidus Lamarck 1822 & 9 & 34 & 3.24 & 7.01 & 2.98 \\
\hline Conus textile Linnaeus 1758 & 8 & 23 & 2.19 & 9.04 & 1.78 \\
\hline Terebra dislocata (Say 1822) & 12 & 71 & 6.77 & 9.78 & 3.8 \\
\hline Harpa costata Linnaeus 1758 & 3 & 4 & 0.38 & 6.00 & 0.65 \\
\hline Harpa davidis Röding 1798 & 2 & 4 & 0.38 & 3.00 & 0.78 \\
\hline Vasum muricatum (Born 1778) & 10 & 23 & 2.19 & 10.54 & 1.56 \\
\hline Bulla striata Bruguiere 1792 & 10 & 43 & 4.10 & 8.94 & 2.87 \\
\hline
\end{tabular}


Distribution: In the present study, this species is recorded from 8 stations and it has diversity 7.3 and a standard deviation 1.87 (table 2). It has a medium areal distribution and is represented by a low number of shells in the study area. Ebaid Alla 1988 described it along the Red Sea coastal plain between Marsa Alam and Ras Banas and recorded in Pleistocene of Sinai by Abed 1982.

Ecology: It is generally found in sandy bottoms. It is common in tidal and littoral zone of marine environment. It is including running, slowly flowing and stagnant water.

Relative abundance: El Malaha Rayan offshore area, $1.91 \%$ of mollusk fauna

Order Mytiloida

In El Malaha Rayan offshore area, this order includes one species. This species live in the shallow water, agitated currents and turbid water. They are associated with many species of aquatic plants.

Superfamily Mytilacea

Family Mytilidae

Subfamily Mytilinae

Genus Modiolus Lamarck 1799

2- Modiolus auriculatus Krauss 1848

Pl. 1, Fig. 2a,b

Distribution: In the present study, this species is recorded from 8 stations (table 4). It has a medium areal distribution and is represented by a medium number of shells. It has diversity 7.59 and a standard deviation 2.92 (table 4). Bernard 1964 is described this species from South Africa, Madagascar and Red Sea Also Ebaid Alla 1988 described it along the Red Sea coastal plain between Marsa Alam and Ras Banas.

Ecology: It is generally found in sand and interspaces between rock coral. It lives in slowly currents, warm water, shallow and calm water. It usually occurs in colonies on and under rocky limestone ledges near the shoreline associated with many species of aquatic plants. It is common in tidal and littoral zone of marine environment and highly significant in tidal zone.

Relative abundance: El Malaha Rayan offshore area $3.43 \%$ of mollusk fauna

\section{Subclass Heterodonta}

Order Veneroida

In El Malaha Rayan offshore area, this order includes 12 species (table 5). These species live in the shallow water, agitated currents and turbid water. They are associated with many species of aquatic plants.

Superfamily Chamacea

\section{Family Chamidae}

Genus Chama Linnaeus 1758

3- Chama squamosa (Solander 1761)

Pl. 1, Fig. 3a,b

Distribution: In the present study, this species is recorded from 10 stations (table 4). It has a high areal distribution and is represented by a high number of shells. It has diversity 8.26 and a standard deviation 5.74 (table 4). Ebaid Alla 1988 described it from beach of the Red Sea coastal plain between Marsa Alam and Ras Banas.

Ecology: It is generally found in sand and rocky beach. It lives in slowly currents, warm water, shallow and calm water. It is highly significant in tidal zone of marine environment.

Relative abundance: El Malaha Rayan offshore area, $8.29 \%$ of mollusk fauna

\section{Superfamily Mactracea}

Family Mactridae

Subfamily Mactrinae

Genus Mactra Linnaeus 1767

4- Mactra glauca Born 1778

Pl. 1, Fig. 4a,b

Distribution: In the present study, this species is recorded from 6 stations (table 4). It has a medium areal distribution and is represented by a low number of shells. It has diversity 7.16 and a standard deviation 1.68 (table 4). Ebaid Alla 1988 described it from beach of the Red Sea coastal plain between Marsa Alam and Ras Banas.

Ecology: It is generally found in sand beach. It lives in agitated currents, warm and shallow water. It is common in tidal and littoral zone of marine environment.

Relative abundance: El Malaha Rayan offshore area, $1.62 \%$ of mollusk fauna

\section{Superfamily Tellinacea \\ Family Psammobiidae}

\section{Subfamily Psammobiinae}

Genus Asaphis Modeer 1793

5- Asaphis deflorata (Linnaeus 1758)

Pl. 1, Fig. 5a,b

Distribution: In the present study, this species is recorded from 8 stations (table 4). It has a medium areal distribution and is represented by a low number of shells. It has diversity 6.78 and a standard deviation 2.57 (table 4). It is recorded by Ebaid Alla 1988 from beach of the Red Sea coastal plain between Marsa Alam and Ras Banas and also Dance 1974 and Lindner 1982 are 
recorded from Atlantic Ocean, Indian Ocean and Red Sea.

Ecology: It is generally found in sand beach. It lives in agitated currents, warm and shallow water. It is common in tidal and littoral zone of marine environment.

Relative abundance: El Malaha Rayan offshore area, $2.67 \%$ of mollusk fauna

Superfamily Tellinacea

Family Tellinidae

Subfamily Tellininae

Genus Tellina Linnaeus 1758

6- Tellina pulchella Lamarck 1818

Pl. 1, Fig. 6a,b

Distribution: In the present study, this species is recorded from 6 stations (table 4). It has a medium areal distribution and is represented by a low number of shells. It has diversity 5.04 and a standard deviation 2.07 (table 4). It is described by El Halaby 2004 from beach of the Abu Sumah bay, North Safaga, Red Sea coast.

Ecology: It is generally found in sand beach and it lives in agitated currents, warm and shallow marine environment.

Relative abundance: El Malaha Rayan offshore area, $1.62 \%$ of mollusk fauna

\section{7- Tellina radiata Linnaeus 1758}

Pl.1, Fig. 7a

Distribution: In the present study, this species is recorded from 10 stations (table 4). It has a high areal distribution and is represented by a low number of shells. It has diversity 12.75 and a standard deviation 1.17 (table 4). It is described by El Halaby 2004 from beach of the Abu Sumah bay, North Safaga, Red Sea coast.

Ecology: It is generally found in sand beach and it lives in agitated currents, warm and shallow marine environment. It is highly significant in littoral zone of marine environment.

Relative abundance: El Malaha Rayan offshore area, $1.72 \%$ of mollusk fauna

\section{8-Tellina rugosa Born 1778}

Pl. 1, Fig. 8a,b

Distribution: In the present study, this species is recorded from 8 stations (table 4). It has a high areal distribution and is represented by a low number of shells. It has diversity 10 and a standard deviation 1.3 (table 4). It is described by El Halaby 2004 from beach of the Abu Sumah bay, North Safaga, Red Sea coast.
Ecology: It is generally found in sand beach and it lives in agitated currents, warm and shallow marine environment.

Relative abundance: El Malaha Rayan offshore area, $1.53 \%$ of mollusk fauna

Superfamily Tridacnacea

Family Tridacnidae

Genus Tridacna Bruguiere 1797

9- Tridacna gigas (Linnaeus 1758)

Pl. 1, Fig. 9a,b

Distribution: In the present study, this species is recorded from 6 stations (table 4). It has a medium areal distribution and is represented by a low number of shells. It has diversity 6.56 and a standard deviation 1.6 (table 4). Ebaid Alla 1988 described it from beach of the Red Sea coastal plain between Marsa Alam and Ras Banas. This species is recorded from Red Sea, East Africa and Philippine by Dance 1974 and Oliver 1980. Also it is recorded from the Pleistocene of Zanzibar by Cox 1927 and Pleistocene of Sinai by Abed 1982. Also El Halaby 2004 described this species from the Abu Sumah bay, North Safaga, Red Sea coast.

Ecology: It is generally found in sand and rocky beach. It lives in agitated currents, warm and turbid water and shallow marine environment.

Relative abundance: El Malaha Rayan offshore area, $1.14 \%$ of mollusk fauna

\section{0- Tridacna squamosa Lamarck 1819}

Pl. 1, Fig. 10a,b

Distribution: In the present study, this species is recorded from 6 stations (table 4). It has a medium areal distribution and is represented by a low number of shells. It has diversity 5.5 and a standard deviation 1.48 (table 4). It is recorded by El Halaby 2004 from the Abu Sumah bay, North Safaga, Red Sea coast.

Ecology: It is generally found in sand and rocky bottom of marine environment. It lives in agitated currents, warm and turbid water and shallow marine environment.

Relative abundance: El Malaha Rayan offshore area, $1.43 \%$ of mollusk fauna

Superfamily Veneracea

Family Veneridae

Genus Venerupis Lamarck 1801

11-Venerupis aurea Gmelin 1791

Pl. 1, Fig. 11a,b

Distribution: In the present study, this species is recorded from 8 stations (table 4). It has a wide areal distribution and is represented by a high 
number of shells. It has diversity 11.05 and a standard deviation 1.42 (table 4). Ebaid Alla 1988 described it from beach of the Red Sea coastal plain between Marsa Alam and Ras Banas.

Ecology: It is generally found in coralline sandy beach. It is highly significant in tidal zone of marine environment (table 3).

Relative abundance: El Malaha Rayan offshore area, $2.76 \%$ of mollusk fauna

Genus Circe Schumacher 1817

12- Circe pectinata (Linnaeus 1758)

Pl. 1, Fig. 12a,b

Distribution: In the present study, this species is recorded from 11 stations (table 4). It has a wide areal distribution and is represented by a high number of shells. It has diversity 8.29 and a standard deviation 2.27 (table 4). Ebaid Alla 1988 described it from beach of the Red Sea coastal plain between Marsa Alam and Ras Banas.

Ecology: It is generally found in coralline sandy beach and it lives in agitated currents, warm and shallow marine environment. It is common in tidal and littoral zone of marine environment and highly significant in tidal zone (table 3 ).

Relative abundance: El Malaha Rayan offshore area, $8.67 \%$ of mollusk fauna

\section{3- Circe scripta Linnaeus 1758}

Pl. 1, Fig. 13a,b

Distribution: In the present study, this species is recorded from 7 stations (table 4). It has a medium areal distribution and is represented by a low number of shells. It has diversity 8.9 and a standard deviation 5.4 (table 4). Dance 1974 recorded this species from Indian Ocean and Abed 1982 recorded it from the Pleistocene of Sinai. Ebaid Alla 1988 described it from beach of the Red Sea coastal plain between Marsa Alam and Ras Banas.

Ecology: It is generally found in coralline sandy beach and it lives in agitated currents, warm and shallow marine environment.

Relative abundance: El Malaha Rayan offshore area, $1.91 \%$ of mollusk fauna

Subfamily Venerinae

Genus Venus Linnaeus 1758

14-Venus reticulata Linnaeus 1758

Pl. 1, Fig. 14a,b

Distribution: In the present study, this species is recorded from 9 stations (table 4). It has a wide areal distribution and is represented by a low number of shells. It has diversity 5.94 and a standard deviation 2.15 (table 4). Ebaid Alla 1988 described it from beach of the Red Sea coastal plain between Marsa Alam and Ras Banas.

Ecology: It is generally found in coralline sandy beach. It is common in tidal and littoral zone of marine environment (table 3 ).

Relative abundance: El Malaha Rayan offshore area, $2 \%$ of mollusk fauna

Class Gastropoda

In El Malaha Rayan offshore area, the five orders of gastropoda are recorded Archaeogastropoda, Caenogastropoda, Mesogastropoda, Neogastropoda and Pleurocoela. These orders include in the area 14 genera (table 5), which are known to live in marine water with agitated currents, warm and sim-clear water.

Subclass Prosobranchia

Order Archaeogastropoda

In El Malaha Rayan offshore area, this order is include 7 species (table 5). These species are live in the quite currents, shallow, warm and clear water. They are associated with many species of aquatic plants.

Suborder Trochina

Superfamily Trochacea

Family Turbinidae

Subfamily Monodontinae

Genus Bathybembix Crosse 1893

15- Bathybembix argenteonitens (Lschke 1871)

Pl. 2, Fig. 1

Distribution: In the present study, this species is recorded from 5 stations (table 4). It has a medium areal distribution and is represented by a low number of shells. It has diversity 7.2 and a standard deviation 1.06 (table 4). El Halaby 2004 described this species from Abu Sumah bay, north Safaga, Red Sea coast.

Ecology: It is generally found in sand beach and it lives in quite currents, warm, shallow and clear water.

Relative abundance: El Malaha Rayan offshore area, $0.86 \%$ mollusk fauna

Genus Tegula Lesson 1835

16- Tegula fasciata (Born 1778)

Pl. 2, Fig. 2

Distribution: In the present study, this species is recorded from 6 stations (table 4). It has a medium areal distribution and is represented by a low number of shells. It has diversity 12 and a 
standard deviation 0.87 (table 4). El Halaby 2003 recorded this species from Old Quay bay, Ras Mohammed National Park, Gulf of Aqaba and also El Halaby 2004 is described it from the Abu Sumah bay, North Safaga, Red Sea coast.

Ecology: It is generally found in sand and sometimes in rocky beach. It lives in slowly currents, warm, shallow, clear and calm water. It usually lives on rocky limestone or in coarse sand. It is common in tidal and littoral zone of marine environment and highly significant in littoral zone (table 3).

Relative abundance: El Malaha Rayan offshore area, $0.86 \%$ of mollusk fauna

\section{7- Tegula omphalius Philippi 1847}

Pl. 2, Fig. 3

Distribution: In the present study, this species is recorded from 6 stations (table 4). It has a medium areal distribution and is represented by a low number of shells. It has diversity 6.7 and a standard deviation 1.67 (table 4). Ziko et al. 2001 are described from recent sediment of $\mathrm{El}$ Hamrawein, Gemsha and Gebel Zeit in the Red Sea coastal plain.

Ecology: It is generally found in sand and sometimes in rocky beach. It lives in slowly currents, warm, shallow, clear and calm water and it usually lives on rocky limestone or in coarse sand.

Relative abundance: El Malaha Rayan offshore area, $1.53 \%$ of mollusk fauna

Subfamily Trochinae

Genus Clanculus Montfort 1810

18- Clanculus pharaonium (Linnaeus 1758)

Pl. 2, Fig. 4

Distribution: In the present study, this species is recorded from 5 stations (table 4). It has a medium areal distribution and is represented by a low number of shells. It has diversity 7.2 and a standard deviation 1.06 (table 4). Ziko et al 2001 are described from recent sediment of El Hamrawein, Gemsha and Gebel Zeit in the Red Sea coastal plain. Abed 1982 is recorded this species from Indian Ocean, Red Sea, Gulf of Suez and Gulf of Aqaba. El Halaby 2003 recorded this species from Old Quay bay, Ras Mohammed National Park, Gulf of Aqaba coast Ecology: It is generally found in sand and sometimes in rocky beach. It lives in slowly currents, warm, shallow, clear and calm water and it usually lives on rocky limestone or in coarse sand.
Relative abundance: El Malaha Rayan offshore area, $0.86 \%$ of mollusk fauna

\section{Genus Tectus Montfort 1810}

19- Tectus dentatus (Forskal 1775)

Pl. 2, Fig. 5

Distribution: In the present study, this species is recorded from 7 stations (table 4). It has a medium areal distribution and is represented by a low number of shells. It has diversity 8.27 and a standard deviation 1.34 (table 4). El Halaby 2004 is described it from the Abu Sumah bay, North Safaga, Red Sea coast and also Ebaid Alla 1988 described it along the Red Sea coastal plain between Marsa Alam and Ras Banas. Oliver 1980 is recorded this species from Indian Ocean.

Ecology: It is generally found in sand and sometimes in rocky beach. It lives in slowly currents, warm, shallow, clear and calm water. It usually lives on rocky limestone or in coarse sand. It is common in tidal and littoral zone of marine environment.

Relative abundance: El Malaha Rayan offshore area, $1.33 \%$ of mollusk fauna

Subfamily Umboniinae

Genus Umbonium Link 1807

20- Umbonium giganteum (Lesson 1831)

Pl. 2, Fig. 6

Distribution: In the present study, this species is recorded from 5 stations (table 4). It has a medium areal distribution and is represented by a low number of shells. It has diversity 5.63 and a standard deviation 1.27 (table 4).

Ecology: It is generally found in sand beach. It lives in quite currents, warm, shallow and clear water.

Relative abundance: El Malaha Rayan offshore area, $0.95 \%$ of mollusk fauna

\section{Subfamily Turbininae \\ Genus Turbo Linnaeous 1758}

21- Turbo argyrostomus Linnaeus 1758

Pl. 2, Fig. 7

Distribution: In the present study, this species is recorded from 11 stations (table 4). It has a wide areal distribution and is represented by a moderate number of shells. It has diversity 7.97 and a standard deviation 3.74 (table 4).

Ecology: It is generally found in sand beach. It lives in quite currents, warm, shallow and clear water. It is highly significant in tidal and littoral zone of marine environment (table 3 ). 
Relative abundance: El Malaha Rayan offshore area, $4.86 \%$ of mollusk fauna

Order Caenogastropoda

In El Malaha Rayan offshore area, this order is include 2 species (table 5). These species are live in the quite currents, shallow, warm and clear water and they are associated with many species of aquatic plants.

Superfamily Rissoacea

Family Rissoidae

Subfamily Rissoinae

Genus Rissoa Muehfldt 1824

22- Rissoa violacea Desmarest 1814

Pl. 2, Fig. 8

Distribution: In the present study, this species is recorded from 8 stations (table 4). It has a medium areal distribution and is represented by a low number of shells in the study area. It has diversity 7.98 and a standard deviation 2.22 (table 4).

Ecology: It is generally found in medium sandy bottom and sometimes in the rocky of limestone. It lives common in all kinds of the tidal and littoral zone of water and it is including running, slowly flowing. It is common in tidal and littoral zone of marine environment and highly significant in littoral zone (table 3).

Relative abundance: El Malaha Rayan offshore area, $2.57 \%$ of mollusk fauna

Subfamily Barleeiinae

Genus Barleeia J. Adams 1795

23- Barleeia rubra (J. Adams 1795)

Pl. 2, Fig. 9

Distribution: In the present study, this species is recorded from 7 stations (table 4). It has a medium areal distribution and is represented by a low number of shells in the study area. It has diversity 6.1 and a standard deviation 2.81 (table 4). El Halaby 2003 recorded this species from Old Quay bay, Ras Mohammed National Park, Gulf of Aqaba coast.

Ecology: It is generally found in medium or coarse sandy bottom and sometimes in the rocky of limestone. It is common in the tidal and littoral zone of water and highly significant in littoral zone (table 3). It is including running, slowly flowing in running water and it is recorded in quite currents, clear, calm and warm water.

Relative abundance: El Malaha Rayan offshore area, $2.67 \%$ of mollusk fauna
Order Mesogastropoda

In El Malaha Rayan offshore area, this order is include 2 species (table 5). These species are live in the quite currents, shallow, warm and clear water. They are associated with many species of aquatic plants.

Superfamily Epitoniacea

Family Epitoniidae

Genus Amaea H.A. Adams 1853

24- Amaea magnifica (Sowerby 1844)

Pl. 2, Fig. 10

Distribution: In the present study, this species is recorded from 8 stations (table 4). It has a medium areal distribution and is represented by a low number of shells in the study area. It has diversity 7.38 and a standard deviation 2.64 (table 4). El Halaby 2004 described this species from the Abu Sumah bay, North Safaga, Red Sea coast and it is recorded by El Halaby 2003 in lake Burullus protectorate.

Ecology: It is generally found in coarse sandy bottom and sometimes in the rocky of limestone. It is common in the tidal and littoral zone of water. It is including running, slowly flowing in running water and it is recorded in quite currents, clear, calm and warm water.

Relative abundance: El Malaha Rayan offshore area, $2.96 \%$ of mollusk fauna

\section{Superfamily Strombacea \\ Family Strombidae \\ Genus Strombus Linnaeus 1758 \\ 25-Strombus gibberulus albus Morch 1852 \\ Pl. 2, Fig. 11}

Distribution: In the present study, this species is recorded from 12 stations (table 4). It has a wide areal distribution and is represented by a moderate number of shells in the study area. It has diversity 8.31 and a standard deviation 4.06 (table 4). Dance 1974 recorded this species from Indian Ocean and also Oliver 1980 recorded from Red Sea and Kenya. El Halaby 2004 described it from the Abu Sumah bay, North Safaga, Red Sea coast.

Ecology: It is generally found in the rocky bottom of limestone and it is significant in the littoral zone of environment (table 3). It is including running, slowly flowing in running water and it is recorded in quite currents, clear, calm and warm water.

Relative abundance: El Malaha Rayan offshore area, $5.62 \%$ of mollusk fauna 
Order Neogastropoda

In El Malaha Rayan offshore area, this order is include 9 species (table 5). These species are live in the quite currents, shallow, warm and clear water. They are associated with many species of aquatic plants.

Superfamily Conacea

Family Conidae

Genus Conus Linnaeus 1758

26- Conus daucus Bruguiere 1792

Pl. 2, Fig. 12

Distribution: In the present study, this species is recorded from 12 stations (table 4). It has a wide areal distribution and is represented by a high number of shells in the study area. It has diversity 9.14 and a standard deviation 5.79 (table 4). El Halaby 2004 described it from the Abu Sumah bay, North Safaga, Red Sea coast.

Ecology: It is generally found in sandy and sometimes on the rocky of limestone. It is highly significant in the tidal and littoral zone of water (table 3). It is including running, slowly flowing. In running water, they have been found attached to rubber wheels, plastic packets, debris and rocks.

Relative abundance: El Malaha Rayan offshore area, $9.82 \%$ of mollusk fauna

\section{7- Conus arenatus Bruguiere 1792}

Pl. 2, Fig. 13

Distribution: In the present study, this species is recorded from 8 stations (table 4). It has a medium areal distribution and is represented by a low number of shells in the study area. It has diversity 7.31 and a standard deviation 2.38 (table 4). Ebaid Alla 1988 recorded this species along the Red Sea coastal plain between Marsa Alam and Ras Banas.

Ecology: It is generally found in sandy and sometimes on the rocky of limestone. It is highly significant in the littoral zone (table 3). It is including running, slowly flowing. In running water, they have been found attached to rubber wheels, plastic packets, debris and rocks.

Relative abundance: El Malaha Rayan offshore area, $2.57 \%$ of mollusk faun

\section{8- Conus glaucus Linnaeus 1758}

Pl. 2, Fig. 14

Distribution: In the present study, this species is recorded from 9 stations (table 4). It has a wide areal distribution and is represented by a low number of shells in the study area. It has diversity 7.02 and a standard deviation 2.45 (table 4).
Ebaid Alla 1988 recorded this species along the Red Sea coastal plain between Marsa Alam and Ras Banas.

Ecology: It is generally found in sandy and sometimes on the rocky of limestone. It is highly significant in the littoral zone (table 3 ). It is including running, slowly flowing. In running water, they have been found attached to rubber wheels, plastic packets, debris and rocks.

Relative abundance: El Malaha Rayan offshore area, $2.57 \%$ of mollusk faun

\section{9- Conus flavidus Lamarck 1822}

Pl. 2, Fig. 15

Distribution: In the present study, this species is recorded from 9 stations (table 4). It has a wide areal distribution and is represented by a high number of shells in the study area. It has diversity 7.01 and a standard deviation 2.98 (table 4). Ebaid Alla 1988 recorded this species along the Red Sea coastal plain between Marsa Alam and Ras Banas.

Ecology: It is generally found in sandy and sometimes on the rocky of limestone. It is common in the tidal and littoral zone. It is including running, slowly flowing. In running water, they have been found attached to rubber wheels, plastic packets, debris and rocks.

Relative abundance: El Malaha Rayan offshore area, 3.24\% of mollusk faun

\section{0- Conus textile Linnaeus 1758}

Pl. 2, Fig. 16

Distribution: In the present study, this species is recorded from 8 stations (table 4). It has a wide areal distribution and is represented by a low number of shells in the study area. It has diversity 9.04 and a standard deviation 1.78 (table 4). Sharabati 1984 described this species from red sea. Ebaid Alla 1988 recorded this species along the Red Sea coastal plain between Marsa Alam and Ras Banas.

Ecology: It is generally found in sandy and sometimes on the rocky of limestone. It is highly significant in the littoral zone (table 3 ). It is including running, slowly flowing. In running water, they have been found attached to corals, rubber wheels, plastic packets, debris and rocks. Relative abundance: El Malaha Rayan offshore area, $2.19 \%$ of mollusk faun

\section{Family Terebridae}

Genus Terebra Bruguiere 1789

31- Terebra dislocata (Say 1822)

Pl. 2, Fig. 17 
Distribution: In the present study, this species is recorded from 12 stations (table 4). It has a wide areal distribution and is represented by a high number of shells in the study area. It has diversity 9.78 and a standard deviation 3.8 (table 4). Ebaid Alla 1988 recorded this species along the Red Sea coastal plain between Marsa Alam and Ras Banas.

Ecology: It is generally found in sandy and sometimes on the rocky of limestone. It is highly significant in the littoral zone (table 3 ). It is including running, slowly flowing. In running water, they have been found attached to rubber wheels and rocks.

Relative abundance: El Malaha Rayan offshore area, $6.77 \%$ of mollusk fauna

Superfamily Volutacea

Family Harpidae

Genus Harpa Walch 1771

32- Harpa costata Linnaeus 1758

Pl. 2, Fig. 18

Distribution: In the present study, this species is recorded from 3 stations (table 4). It has a small areal distribution and is represented by a rare number of shells in the study area. It has diversity 6 and a standard deviation 0.65 (table 4).

Ecology: It is generally found in sandy and sometimes on the rocky of limestone. It is common in the littoral zone of water. It is including running, slowly flowing. In running water, they have been found attached to rubber wheels and rocks.

Relative abundance: El Malaha Rayan offshore area, $0.38 \%$ of mollusk fauna

\section{3-Harpa davidis Röding 1798}

\section{Pl. 2, Fig. 19}

Distribution: In the present study, this species is recorded from 2 stations (table 4). It has a small areal distribution and is represented by a rare number of shells in the study area. It has diversity 3 and a standard deviation 0.78 (table 4).

Ecology: It is generally found in sandy and sometimes on the rocky of limestone. It is common in the littoral zone. It is including running, slowly flowing. In running water, they have been found attached to rubber wheels and rocks.

Relative abundance: El Malaha Rayan offshore area, $0.38 \%$ of mollusk fauna

Family Turbinellidae

Genus Vasum Linnaeus 1758

34- Vasum muricatum (Born 1778)

\section{Pl. 2, Fig. 20}

Distribution: In the present study, this species is recorded from 10 stations (table 4). It has a wide areal distribution and is represented by a low number of shells in the study area. It has diversity 10.54 and a standard deviation 1.56 (table 4).

Ecology: It is generally found in medium or coarse sandy bottom and sometimes in the rocky of limestone. It is highly significant in the littoral zone (table 3). It is including running, slowly flowing in running water and it is recorded in quite currents and clear, calm and warm water.

Relative abundance: El Malaha Rayan offshore area, $2.19 \%$ of mollusk fauna

\section{Subclass Opisthobranchia \\ Order Pleurocoela}

In El Malaha Rayan offshore area, this order is include one species (table 5). This species is live in the quite currents, shallow, warm and clear water. They are associated with many species of aquatic plants.

Superfamily Bullacea

Family Bullidae

Genus Bulla Linnaeus 1758

Bulla striata Bruguiere 1792

Pl. 2, Fig. 21

Distribution: In the present study, this species is recorded from 10 stations (table 4). It has a wide areal distribution and is represented by a moderate number of shells in the study area. It has diversity 8.94 and a standard deviation 2.87 (table 4). El Halaby 2004 is described it from the Abu Sumah bay, North Safaga, Red Sea coast and also it is recorded from old Quay bay, Ras Mohammed National Park by El Halaby 2002.

Ecology: It is generally found in medium sandy bottom and sometimes in the rocky of limestone. It is highly significant in the littoral zone (table 3 ). It is including running, slowly flowing. It is running water.

Relative abundance: El Malaha Rayan offshore area, $4.1 \%$ of mollusk fauna.

\section{Conclusion}

The analysis of variance proved to be useful in the recognition of significant species in segregating cluster groups of samples. These cluster groups are determined depending on their content of Mollusk species. The highly significant species can be considered as 
important species for the recognition of various environmentally distinct areas in the investigated locality.

There are two groups of cluster analyses in the dendogram. The first group (A) located in the Tidal zone and include 33 Mollusk species (14 species from class Bivalvia and 19 species from class Gastropoda). The other group (B) located in the littoral zone and include 35 Mollusk species (14 species from class Bivalvia and 21 species from class Gastropoda).

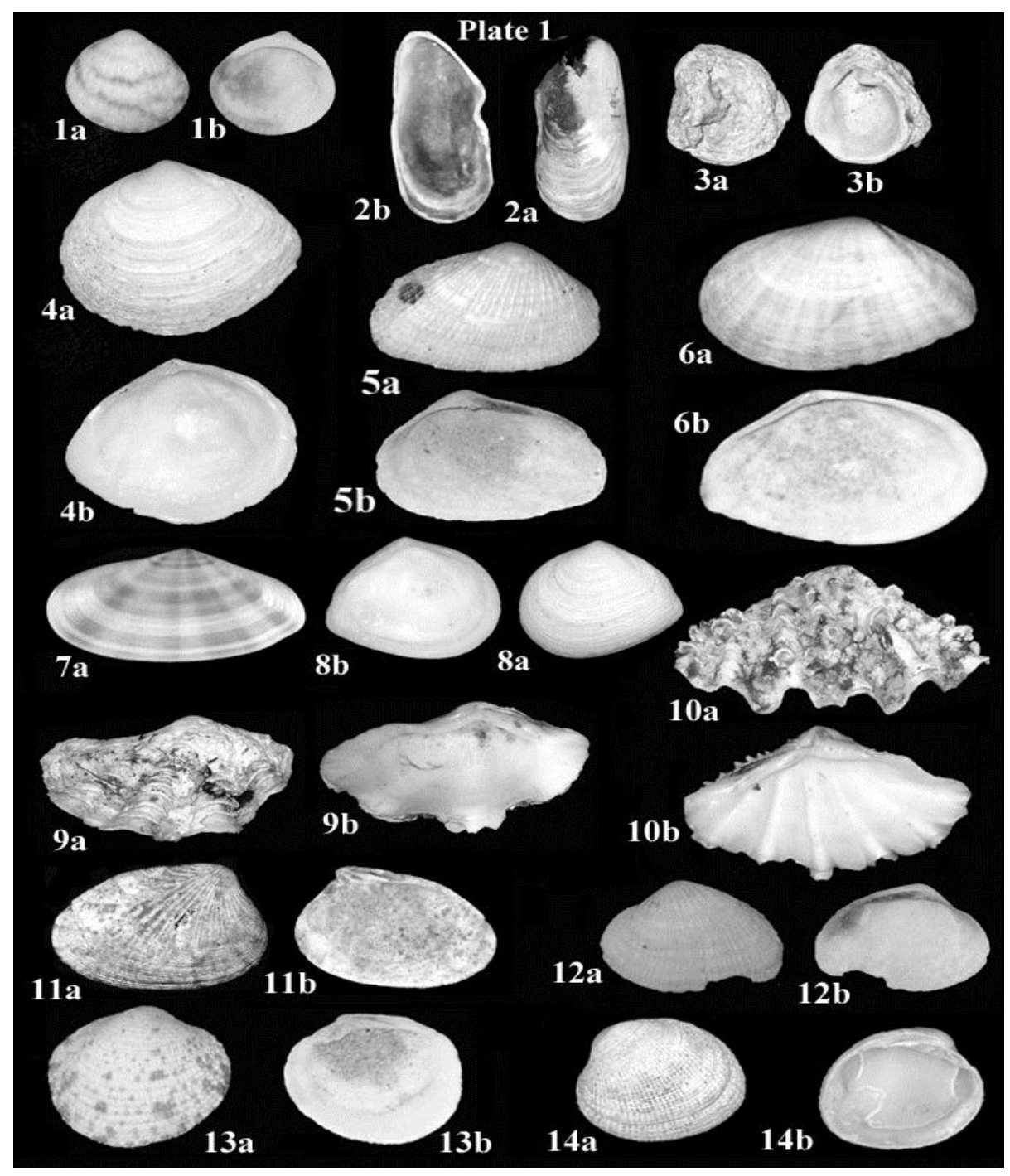

1- Glycymeris pectunculus (Linnaeus 1780)

2- Modiolus auriculatus Krauss 1848

3- Chama squamosa (Solander 1761)

4- Mactra glauca Born 1778

5- Asaphis deflorata (Linnaeus 1758)

6- Tellina pulchella Lamarck 1818

7- Tellina radiate Linnaeus 1758

8- Tellina rugosa Born 1778

9- Tridacna gigas (Linnaeus 1758)

10- Tridacna squamosa Lamarck 1819

11- Venerupis aurea Gmelin 1791

12- Circe pectinata (Linnaeus 1758)

13- Circe scripta Linnaeus 1758

14- Venus reticulata Linnaeus 1758
1 a dorsal view, $1 \mathrm{~b}$ ventral view, sample 1 $2 \mathrm{a}$ dorsal view, $2 \mathrm{~b}$ ventral view, sample 1 3 a dorsal view, $3 b$ ventral view, sample 1 $4 \mathrm{a}$ dorsal view, $4 \mathrm{~b}$ ventral view, sample 1 5 a dorsal view, 5 b ventral view, sample 1 6 a dorsal view, $6 \mathrm{~b}$ ventral view, sample 1 7a dorsal view, sample 1

8 a dorsal view, $8 \mathrm{~b}$ ventral view, sample 1 9 a dorsal view, $9 \mathrm{~b}$ ventral view, sample 1 10 a dorsal view, $10 \mathrm{~b}$ ventral view, sample 1 11 a dorsal view, $11 \mathrm{~b}$ ventral view, sample 1 12a dorsal view, $12 \mathrm{~b}$ ventral view, sample 1 13a dorsal view, $13 \mathrm{~b}$ ventral view, sample 1 14a dorsal view, $14 \mathrm{~b}$ ventral view, sample 1 


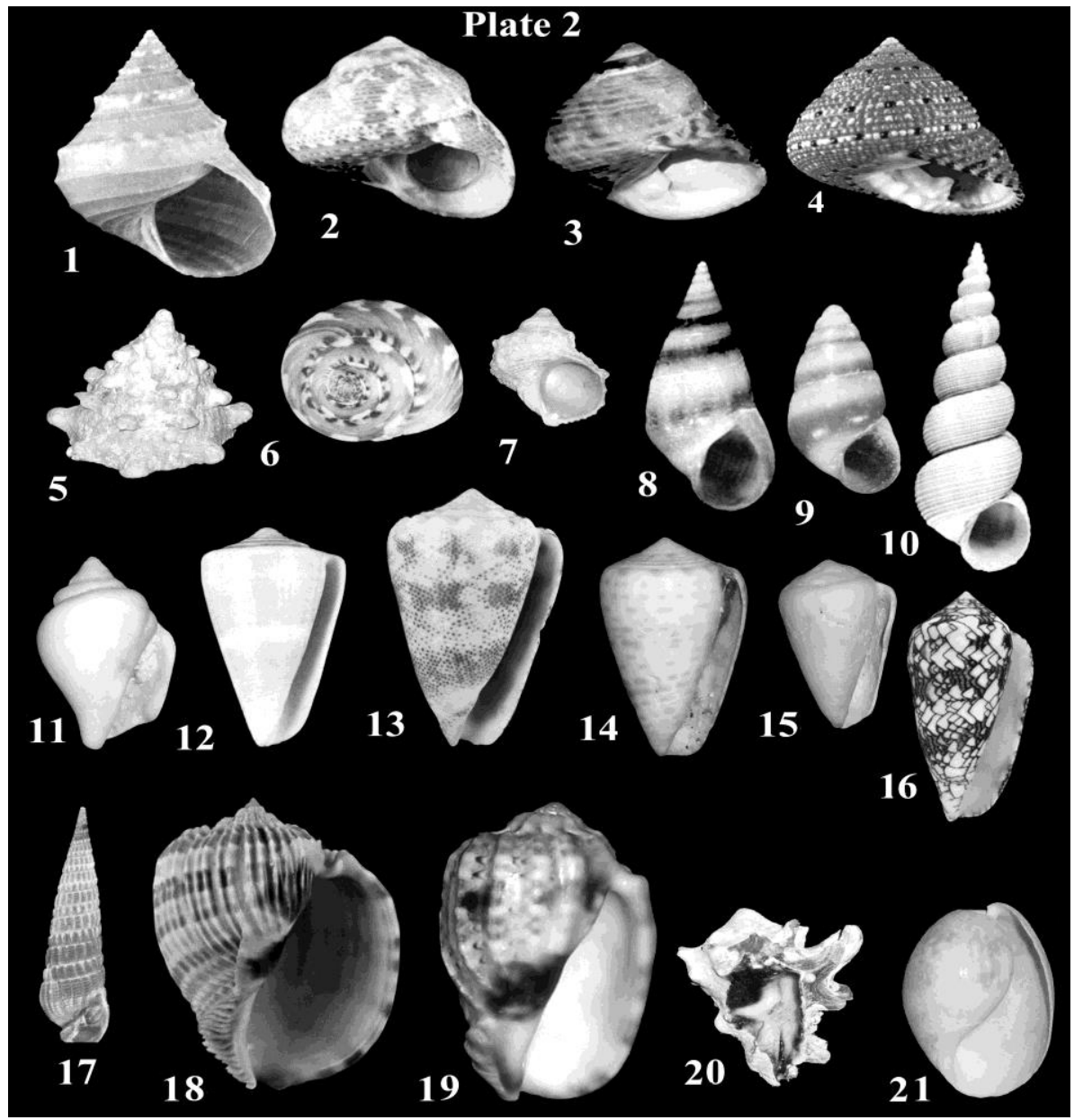

1- Bathybembix argenteonitens (Lschke 1871)

2- Tegula Fasciata (Born 1778)

3- Tegula omphalius Philippi 1847

4- Clanculus pharaonium (Linnaeus 1758)

5- Tectus dentatus (Forskal 1775)

6- Umbonium giganteum (Lesson 1831)

7- Turbo argyrostomus Linnaeus 1758

8- Rissoa violacea Desmarest 1814

9- Barleeia rubra (J. Adams 1795)

10- Amaea magnifica (Sowerby 1844)

11- Strombus gibberulus albus Morch 1852

12- Conus daucus Bruguiere 1792

13- Conus arenatus Bruguiere 1792

14- Conus glaucus Linnaeus 1758

15- Conus flavidus Lamarck 1822

16- Conus textile Linnaeus 1758

17- Terebra dislocata (Say 1822)

18- Harpa costata Linnaeus 1758

19 - Harpa davidis Röding 1798

20- Vasum muricatum (Born 1778)

21- Bulla striata Bruguiere 1792

sample 12 sample 12 sample 12 sample 12 sample 12 sample 12 sample 12 sample 12 sample 12 sample 12 sample 12 sample 11 sample 12 sample 12 sample 10 sample 12 sample 12 sample 12 sample 10 sample 12 sample 12
Group (A) include 33 species, but only 6 species are highly significant ( Modiolus auriculatus, Chama squamosa, Venerupis aurea, Circe pectinata, Turbo argyrostomus and Conus 
daucus). These species exists in warm turbid water mostly caused by flash floods of and they represent the tidal zone.

Group (B) include 35 species, but only 14 species are highly significant (Tellina radiata, Circe pectinata, Tegula Fasciata, Turbo argyrostomus, Rissoa violacea, Barleeia rubra, Strombus gibberulus albus, Conus daucus, Conus arenatus, Conus glaucus, Conus textile, Terebra dislocata, Vasum muricatum and Bulla striata). These species exist in warm, turbid water and agitate currents usually caused by flash floods. They represent the littoral zone.

\section{References}

Abed, M.M., 1982: Quaternary fauna from Gabal Tanka, Sinai Peninsula, Egypt. Bull. Fac. Sci., Mansoura Univ., no.9, 227 - 307 pp.

Ball, J. 1937: The water supply of Mersa Matruch. Survey and Mine dept. vol. 42

Cox, 1927: Report on the palaeontology of the Zanzibar Protectorate, Molluscz, 13- 102 pp.

Dance, S.P., 1974: The Encyclopedia of shells. Blandford Press. 288 pp.

Ebaid Alla, N. A., 1988: Recent invertebrates along the Red Sea coastal plain between Marsa Alam and Ras Banas. M. Sc. Thesis, Assiut Univ., Egypt, 239 pp.
El Halaby, O. M. 2003: Some statistical study on the distribution of Recent Mollusca shells assemblages from Old Quay Bay, Ras Mohammed National Park, Gulf of Aqaba coast, Egypt, annuls geol. Surv. Egypt, V. XXV (2002) 101- 114 pp.

El Halaby, O.M. 2003: Taxonomy and ecology of 19 species of Recent Mollusca in Lake Burullus Protctorate, Annuals Geol. Surv. Egypt, V. XXV (2002), $161-173$ pp.

El Halaby, O.M. 2004: Distribution of the Assemblages of Molluscan Shells As a Reflection of Sedimentation in the Northern Part of the Abu Sumah Bay, North Safaga, Red Sea Coast, Egypt, Annuals Geol. Surv. Egypt, V. XXVI (2003) 295315 pp.

Lindner, G., 1982: BLV Bestimmungsbuch Muschen, Schnecken der Weltmeere, BLV Verlagsgesellschaft Munchen, Wien, Zurich, 256 pp.

Moore, R.C., (E.D), 1969, 1971: Treatise on Invertebrate Paleontology, part N. Mollusca 6 (Bivalvia), Vols. 1.2 (1969) and 3 (1971). Geological Society of American and Uni. of Kansas. Press, Lawrence, Kansas.

Oliver, A.P.H., 1980: The Hamlyn guide to shells of the world. Hamlyn publishing, London, New York, Sydney, Toronto, 320 pp.

Ziko, A., El Sorogy, A.S., Aly, M.M. \& Nour, H.E., 2001: Sea shells as pollution indicators, Red Sea coast Egypt, Egypt. Jour. Paleontol., V. 1, 97 $113 \mathrm{pp}$.

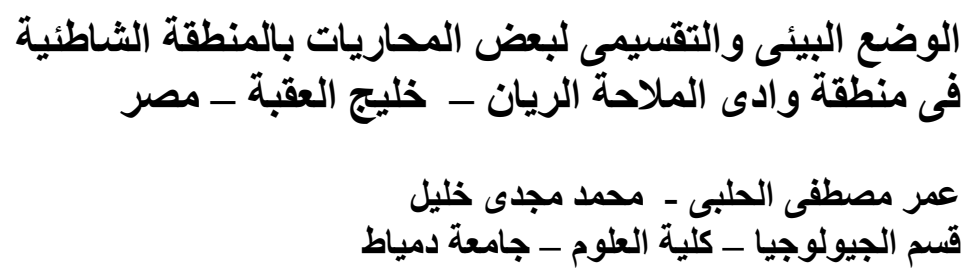

تناول البحث دراسة التقسيم والأوضاع البيئية ل 35 نوع من المحاريات حيث تم تعريفها من 12 عينة

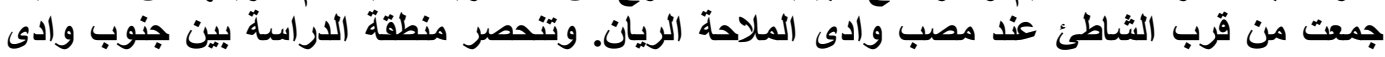

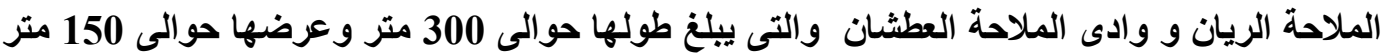

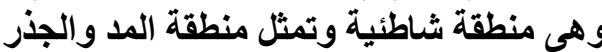

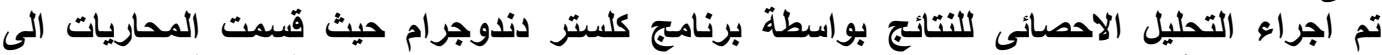
مجموعتين: الأولى (A) وتضم 33نوع وتمثل المحاريات التى تتواجد في المنطقة الدافئة العكرة بسبب التئ 